\title{
STUDI KINETIKA ENDOSPERMA BUAH KELAPA (Cocos nucifera) UNTUK MENINGKATKAN SISTEM IMUNITAS TUBUH TERHADAP INFEKSI VIRUS PADA BATUK PILEK ATAU SELESMA
}

\author{
Herfina Listia ${ }^{1 *}$ \\ ${ }^{1}$ Pendidikan Kimia, FMIPA, Universitas Negeri Padang, Indonesia \\ *Email : herfinalistya@gmail.com
}

\begin{abstract}
Abstrak. Studi ini bertujuan untuk membuat santan dari sari endosperma buah kelapa untuk meningkatkan sistem imunitas tubuh terhadap infeksi virus pada batuk pilek atau selesma. Metode yang dilakukan adalah eksperimen dan uji aktivitas katalitik secara langsung. Tahapan pertama dilakukan dengan pembuatan santan dari sari endosperma atau daging buah kelapa. Uji langsung dilakukan dengan variasi selama 5 hari. Hasil eksperimen membuktikan bahwa santan dari buah kelapa dapat meningkatkan sistem imunitas tubuh terhadap infeksi virus pada batuk pilek atau selesma. Kondisi optimum santan dari buah kelapa tercapai pada penggunaan rutin sebanyak kurang lebih $200 \mathrm{~mL}$ setiap harinya. Penyembuhan ini diduga karena adanya aktivitas katalitik dari santan buah kelapa yang mengandung berbagai zat yang dapat meningkatkan sistem kekebalan tubuh terhadap infeksi virus pada saluran pernapasan.
\end{abstract}

Kata Kunci : bahan alami, buah kelapa, batuk pilek, selesma, santan, infeksi virus, jeruk nipis

\section{Pendahuluan}

Indonesia merupakan negara dengan iklim tropis, dimana dengan iklim tersebut banyak tumbuhan yang dapat tumbuh disekitarnya[1]. Salah satunya tumbuhan kelapa, tumbuhan kelapa mempunyai banyak manfaat dalam kehidupan sehari-hari, mulai dari bagian akar sampai buahnya[2]. Pada buah kelapa itu sendiri, terdapat daging buah kelapa yang biasanya diolah menjadi santan. Santan dari buah kelapa selain dapat diolah sebagai makanan, juga dapat digunakan untuk meredakan masalah batuk pilek atau selesma[3]

Istilah selesma ini hampir sulit ditemukan dalam kehidupan sehari-hari, masyarakat umumnya lebih mengenalnya dengan istilah flu[4], padahal penggunaan kata flu untuk gejala penyakit infeksi saluran pernapasan kurang tepat, karena kata flu berarti penyakit yang disebabkan oleh virus influenza[5]. Sedangkan, penyakit saluran pernapasan tidak hanya dapat disebabkan oleh virus influenza saja. Namun, dapat disebabkan oleh berbagai macam virus 
lainnya[6]. Istilah salesma padahal sudah ada sejak zaman nenek moyang kita terdahulu, namun istilah selesma sebagai istilah bahasa indonesia saat ini hampir terlupakan[7].

Selesma atau penyakit infeksi saluran pernapasan[8] menyebabkan timbulnya berbagai gejala mulai dari demam, pilek meler, hidung mampet, bersin-bersin, batuk, hingga nyeri tenggorokkan[9]. Penyakit ini sangat sering kita jumpai dalam kehidupan sehari-hari baik pada orang dewasa dan terlebih pada anak-anak[10]. Penyakit ini lebih mudah menyerang anak-anak daripada orang dewasa karena daya tahan tubuh anak-anak lebih lemah jika dibandingkan dengan orang dewasa[11].

Selesma ini dapat disebabkan oleh berbagai jenis virus yang biasa menginfeksi saluran pernapasan[12]. Ada banyak jenis virus yang dapat menyebabkan timbulnya gejala selesma, seperti Rhinovirus, Coronavirus, Influenza, Adenovirus, Enterovirus, Metapneumovirus dan masih banyak lagi virus lainnya yang jumlahnya mencapai kurang lebih 200 virus[13]. Penyebab tersering selesma adalah Rhinoviru[14]. Virus lain juga dapat menyebabkan selesma. Seringkali, lebih dari satu jenis virus dapat menyerang dan menyebabkan selesma[15].

Selesma merupakan penyakit saluran pernapasan yang disebabkan oleh virus dan sangat mudah sekali menular, misalnya dari seorang pasien yang ketika batuk atau bersin, namun tidak menutupnya sehingga virus tersebut dapat menyebar melalui udara dan apabila virus tersebut masuk atau terhirup oleh orang lain maka akan sangat mudah untuk orang lain tersebut tertular penyakit selesma yang diderita pasien tersebut[16]. Tanda atau gejalanya mungkin akan muncul dalam waktu kurang dari dua hari setelah orang tersebut berinteraksi dan tertular selesma[17].

Dalam praktik medis, biasanya dokter tidak memeriksa virus apa yang menyebabkan salesma pada pasien yang datang berobat. Hal ini dikarenakan pemeriksaan virus secara teknis cukup sulit untuk dilakukan, dan juga karena biaya pemeriksaannya yang mahal, padahal nyaris tidak ada manfaatnya untuk mengetahui virus apa yang menyebabkan selesma[18]. Karena biasanya selesma dapat sembuh dengan sendirinya[19]. Walaupun selesma tidak dapat menyebabkan kematian. Namun, selesma dapat mengganggu kenyamanan dan mengurangi produktivitas dalam melakukan aktivitas sehari-hari[20].

Untuk meredakan gejala selesma atau batuk pilek dapat digunakan berbagai bahan alami yang sudah sangat banyak tersedia dialam, seperti misalnya kelapa[21]. Buah kelapa ( Cocos 
nucifera ) sangat banyak manfaatnya dalam kehidupan sehari-hari, baik dalam pengolahan makanan maupun kesehatan. Hal ini dikarenakan buah kelapa mengandung berbagai nutrisi yang baik bagi tubuh[22].

Buah kelapa ( Cocos nucifera) terutama daging buahnya mengandung berbagai macam zat yang sangat dibutuhkan oleh tubuh, seperti asam laurat, magnesium, potasium, posfor, folat, seng, selenium, kalsium, tembaga serta vitamin C, vitamin E, dan vitamin K[23]. Selain itu, santan kaya akan zat besi, dimana kandungan zat besi pada santan mencapai $22 \%$ dari kebutuhan tubuh sehari-hari[24]. Adanya kandungan zat besi ini membuat tubuh mampu memproduksi sel darah putih yang dapat berperan sebagai antibodi didalam tubuh kita, sehingga dapat meningkatkan sistem imunitas tubuh dalam menangkaal virus yang menginfeksi saluran pernapasan[25]

Kandungan vitamin $\mathrm{C}$ dan juga asam laurat yang merupakan jenis asam lemak jenuh[26] pada santan dapat sebagai katalis untuk meningkatkan kekebalan tubuh, sehingga dapat meredakan batuk pilek, serta melindungi tubuh dari serangan flu dan juga infeksi virus.[27]

Asam laurat sebagai katalis dapat berperan sebagai anti bakteri, anti mikroba, dan anti jamur sehingga dapat mencegah infeksi tambahan pada saluran pernapasan yang tidak hanya bisa disebabkan oleh virus namun juga yang diakibatkan oleh bakteri[28], dengan cara meningkatkan sistem imun pada tubuh sehingga dapat juga meredakan sakit pada radang tenggorokan.[29]

\section{Metode}

\subsection{Alat dan Bahan}

Peralatan yang dipakai adalah gelas (royalex), sendok (tupperware), baskom (superdeluxe), pisau (doante), saringan (maspion), kamera (oppo Neo5)

Bahan yang digunakan adalah buah kelapa, air (aqua), jeruk nipis

\subsection{Prosedur Kerja}

\subsubsection{Persiapan Sampel}


Sampel buah kelapa diambil dari Desa Kemantan Tinggi, Kec. Air Hangat Timur, Kab. Kerinci, Prov. Jambi , kemudian sampel dibelah menjadi dua bagian, lalu memarut setengah bagiannya.

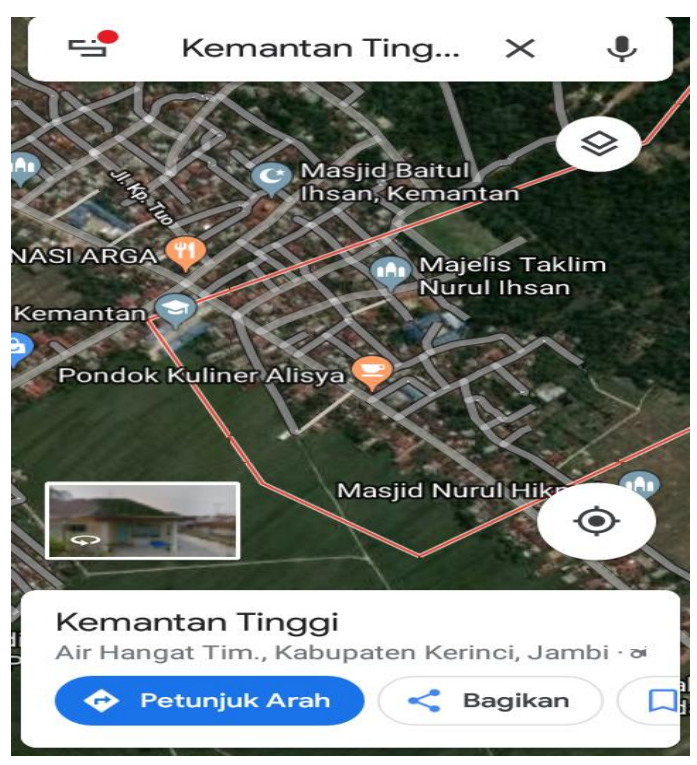

Mencuci bersih jeruk nipis, kemudian memotongnya menjadi dua bagian.

\subsubsection{Pembuatan Sari Endosperma Buah Kelapa (Santan)}

Santan dibuat dengan 200 gram parutan kelapa dengan $240 \mathrm{~mL}$ air, kemudian diperas sampai kira-kira sari dari parutan tersebut sudah keluar semua, lalu saring untuk menghilangkan ampas parutannya.

Kemudian peras sebuah jeruk nipis yang sudah dipotong tadi dan dan masukkan air perasannya ke dalam santan.

Kemudian mengulangi penyaringan santan yang telah ditambahkan jeruk peras tadi, dan memasukkannya ke dalam gelas. Dan santan sebanyak $\pm 200 \mathrm{~mL}$ siap diminum rutin sekali sehari.

\subsubsection{Pengujian Ekstrak}

Ekstrak diujikan pada orang yang mengalami selesma dengan gejala batuk pilek selama 5 hari, dengan jumlah $\pm 200 \mathrm{~mL}$ per hari.

Metode ini dapat dibuat dengan diagram alir, sebagai berikut: 


\section{Persiapan Sampel}
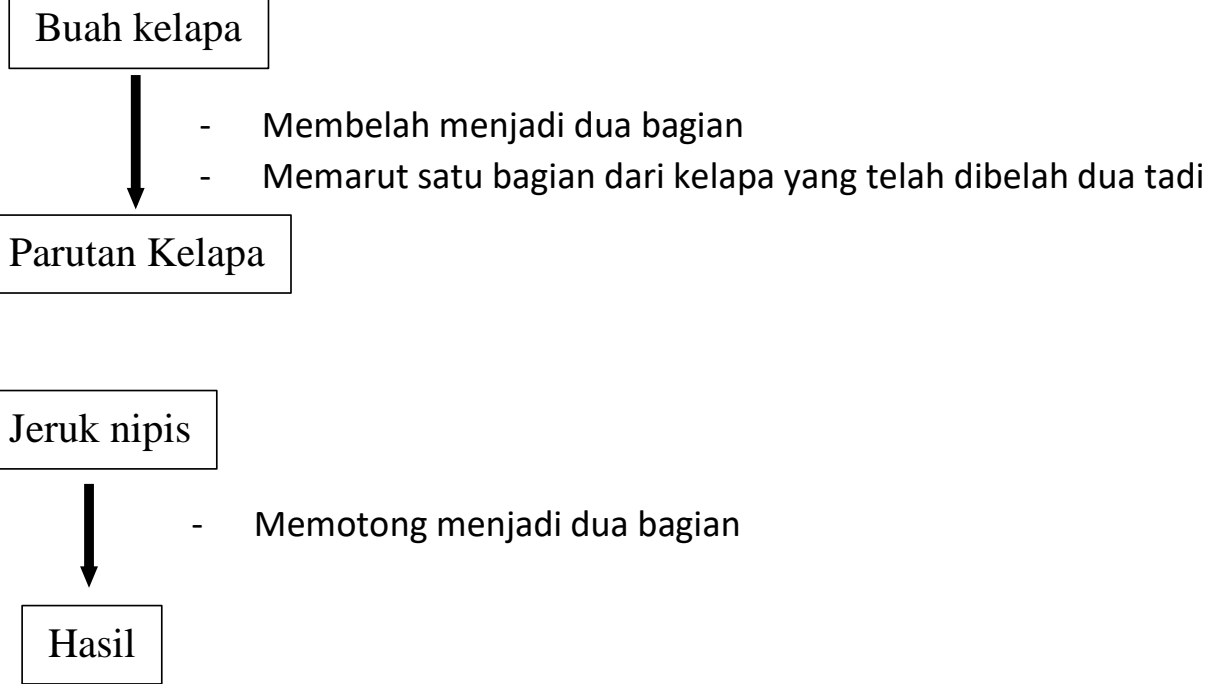

\section{Pembuatan Ekstrak}

\section{Parutan kelapa}

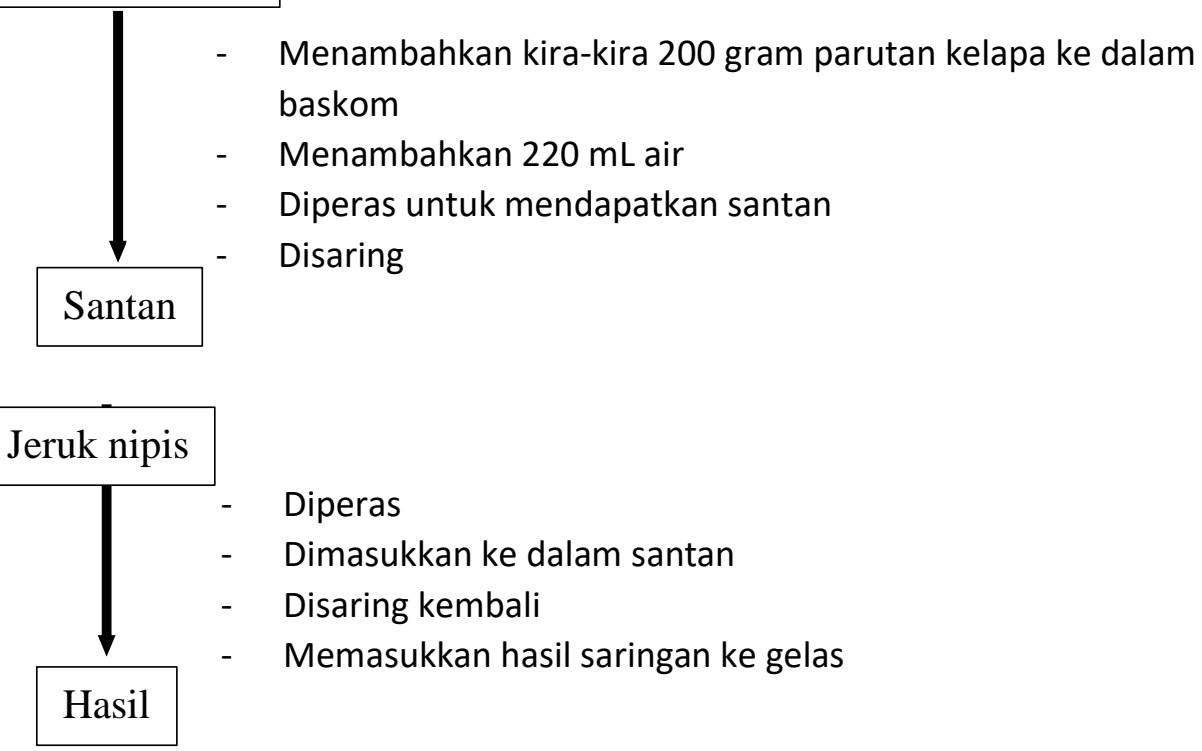

\section{Pengujian Ekstrak}

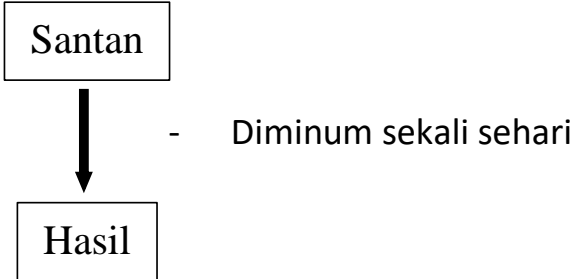




\section{Hasil}

\subsection{Hasil Pembuatan Santan}

Hasil pembuatan santan yang berasal dari 200 gram parutan kelapa dengan $240 \mathrm{~mL}$ air dan juga air perasan satu buah jeruk nipis, menghasilkan santan sebanyak $200 \mathrm{~mL}$ dapat dilihat seperti gambar berikut:

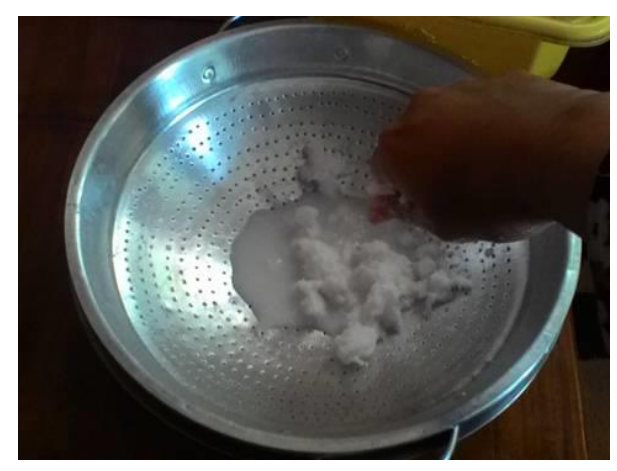

(a)

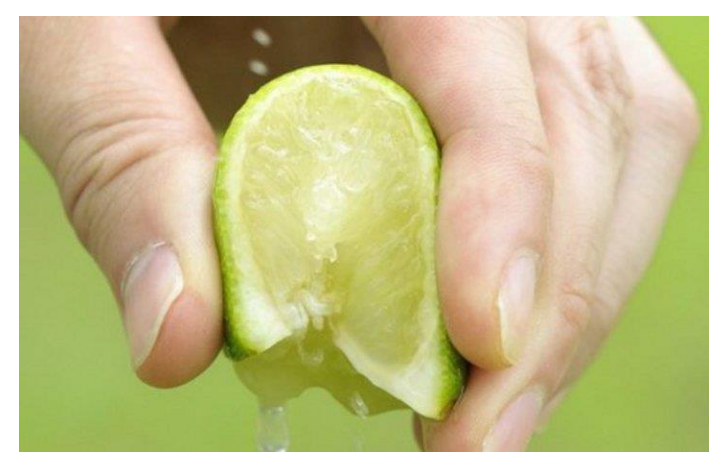

(c)

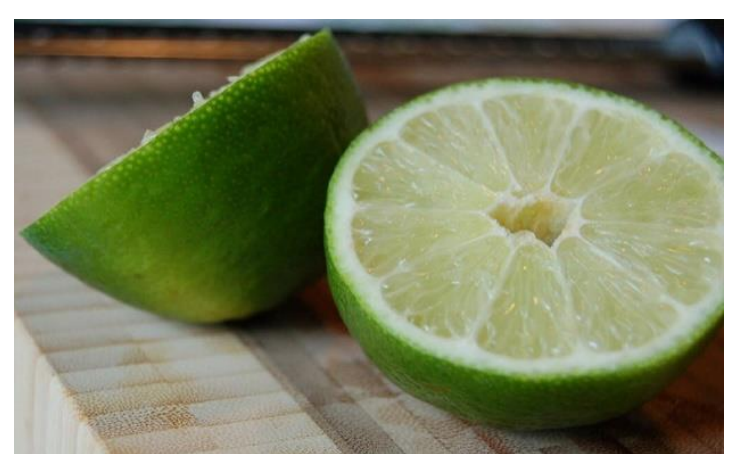

(b)

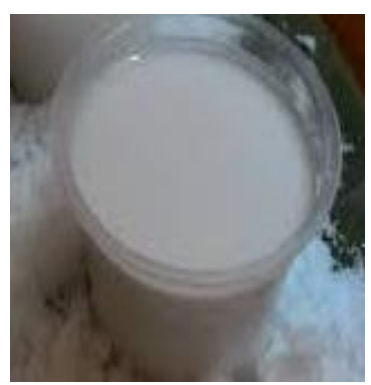

(d)

\subsection{Hasil Uji Coba}

Hasil uji coba yaitu pengujian terhadap orang yang mengalami selesma dengan gejala batuk pilek yang berlangsung selama 5 hari dengan takaran yang sama, dapat dilihat pada tabel berikut:

\begin{tabular}{|c|c|c|}
\hline Hari ke- & Takaran & Frekuensi batuk \\
\hline 1 & $\pm 200 \mathrm{Ml}$ & $\pm 50 \mathrm{kali}$ \\
\hline 2 & $\pm 200 \mathrm{Ml}$ & $\pm 40 \mathrm{kali}$ \\
\hline 3 & $\pm 200 \mathrm{~mL}$ & $\pm 29 \mathrm{kali}$ \\
\hline 4 & $\pm 200 \mathrm{Ml}$ & $\pm 17 \mathrm{kali}$ \\
\hline
\end{tabular}




\begin{tabular}{|l|l|l|}
\hline 5 & $\pm 200 \mathrm{~mL}$ & $\pm 5 \mathrm{kali}$ \\
\hline
\end{tabular}

\section{Pembahasan}

\subsection{Pembuatan}

Langkah pertama, yaitu dilakukan pemarutan terhadap daging buah kelapa. Kemudian hasil parutan tersebut diambil lebih kurang 200 gram, dan dicampurkan dengan air sebanyak $240 \mathrm{~mL}$, kemudian dilakukan pemerasan untuk mengambil santan (sari dari daging buah tersebut). Lalu melakukan penyaringan untuk memisahkan santan dengan ampas parutan kelapa tersebut. Adapun jeruk nipis dibersihkan, kemudian dipotong menjadi dua bagian. Dan dilakukan pemerasan untuk mendapatkan air perasan jeruk nipis tersebut. Kemudian dicampurkan dengan santan yang sudah jadi, melalui saringan agar serat-serat atau biji pada jeruk nipis tidak tercampur ke dalam santan. Dan dihasilkan kurang lebih 200 mL ekstrak.

Pada saat pembuatan santan terdapat beberapa kendala, yaitu saat pemerasan terhadap parutan kelapa dan juga pemerasan terhadap jeruk nipis. Pada saat pemerasan terhadap parutan kelapa masih dilakukan secara manual sehingga sari dari parutan kelapa yang digunakan mungkin tidak keluar semuanya sehingga hasil pemerasan tidak sempurna dan masih terdapat sari didalamnya. Pada saat pemerasan terhadap jeruk nipis, juga mengalami hal yang sama dengan pemerasan terhadap parutan kelapa, dimana masih dilakukan pemerasan secara manual. Selain itu, kendala juga ditemui saat pengambilan sampel atau buah kelapa, dimana pohonnya yang tinggi menyebabkan kesullitan saat mengambilnya.

\subsection{Uji Coba}

Sebanyak kurang lebih $200 \mathrm{~mL}$ hasil yang didapatkan , dilakukan uji coba pada orang yang terkena batuk pilek atau gejala selesma, dimana ekstrak diminum sekali sehari selama 5 hari dengan takaran yang sama. Maka, setelah dilakukan pengujian didapat data seperti yang ditunjukkan grafik berikut:

\section{Grafik Penurunan Frekuensi Batuk pada Batuk Pilek (Gejala Selesma)}

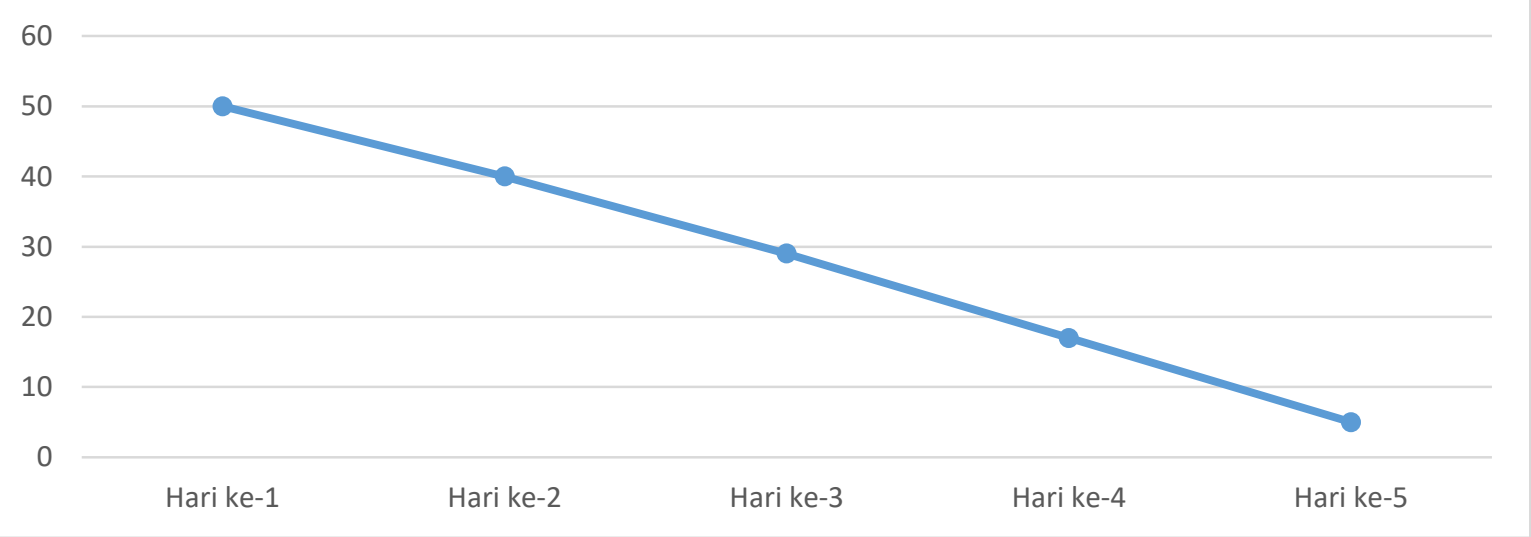


Grafik diatas menunjukkan hubungan antara pengonsumsian santan secara rutin dengan takaran yang sama selama 5 hari berturut-turut dengan penurunan frekuensi batuk pada gejala selesma, yaitu batuk pilek. Grafik tersebut dapat dijelaskan sebagai berikut:

- Pada hari pertama pengujian, frekuensi batuk kurang lebih 50 kali

- Pada hari kedua pengujian, frekuensi batuk turun menjadi kurang lebih 40 kali

- Pada hari ketiga pengujian, frekuensi batuk turun menjadi kurang lebih 29 kali

- Pada hari keempat pengujian, frekuensi batuk turun menjadi kurang lebih 17 kali

- Pada hari kelima pengujian, frekuensi batuk turun menjadi kurang lebih 5 kali

Maka dari grafik dapat disimpulkan bahwa dengan pengonsumsian secara rutin,dengan takaran yang sama dapat meredakan gejala selesma pada batuk pilek.

\subsection{Interaksi}

Endosperma buah kelapa (Cocos nucifera), mengandung berbagai macam zat yang sangat dibutuhkan oleh tubuh, seperti asam laurat, magnesium, potasium, posfor, folat, seng, selenium, kalsium, tembaga serta vitamin C, vitamin E, dan vitamin K. Selain itu, santan atau endosperma buah kelapa ini kaya akan zat besi, dimana kandungan zat besi pada santan mencapai $22 \%$ dari kebutuhan tubuh sehari-hari. Adanya kandungan zat besi ini membuat tubuh mampu memproduksi sel darah putih yang dapat berperan sebagai antibodi didalam tubuh kita, sehingga dapat meningkatkan sistem imunitas tubuh dalam menangkal virus yang menginfeksi saluran pernapasan, yang menyebabkan berbagai gejala selesma seperti batuk pilek.

Kandungan vitamin $\mathrm{C}$ dan juga asam laurat yang merupakan jenis asam lemak jenuh yang terdapat pada santan dapat meningkatkan kekebalan tubuh, sehingga dapat meredakan batuk pilek, serta melindungi tubuh dari serangan flu dan juga infeksi virus.

Asam laurat dapat berperan sebagai anti bakteri, anti mikroba, dan anti jamur sehingga dapat mencegah infeksi tambahan pada saluran pernapasan yang tidak hanya bisa disebabkan oleh virus namun juga yang diakibatkan oleh bakteri, dengan cara meningkatkan sistem imun pada tubuh sehingga dapat juga meredakan sakit pada radang tenggorokan.

Adapun penambahan jeruk nipis pada santan dikarenakan kandungan jeruk nipis yang memiliki kandungan antioksidan jenis flavonoid yang cukup tinggi sehingga dapat membantu santan dalam melawan infeksi virus yang menyebabkan gejala batuk pilek[30]. Selain itu, jeruk nipis sebagai katalis juga dapat digunakan sebagai anti septik alami[31] dan juga dapat menambah rasa saat pengonsumsian santan agar tidak hambar[32]. Jeruk nipis juga kaya akan asam sitrat dimana asam umumnya dapat berperan sebagai katalis[33] dalam reaksi yang terjadi 
pada santan dalam tubuh untuk dapat meningkatkan sistem imunitas tubuh untuk melawan berbagai jenis virus yang dapat menyebabkan batuk pilek atau gejala-gejala selesma lainnya[34].

Jadi, kandungan-kandungan yang terdapat dalam endosperma buah kelapa (Cocos nucifera) ditambah dengan air perasan jeruk nipis dapat berperan dalam meningkatkan sistem imunitas tubuh terhadap infeksi virus batuk pilek atau selesma[35], sehingga setelah beberapa hari pengonsumsian secara rutin maka dapat meredakan batuk pilek dan gejala selesma lainnya.

\section{Kesimpulan}

- Ekstrak atau santan dari endosperma buah kelapa dapat dibuat dari 200 gram parutan kelapa dengan $220 \mathrm{~mL}$ air ditambah dengan air perasan satu buah jeruk nipis

- Campuran santan buah kelapa dapat meningkatkan sistem imunitas tubuh sehingga dapat melawan infeksi virus terhadap saluran pernapasan yang dapat menyebabkan batuk pilek dan gejala-gejala selesma lainnya. Dengan pengonsumsian rutin sebanyak kurang lebih $200 \mathrm{~mL}$ perhari dapat menurunkan frekuensi batuk pilek secara bertahap sampai batuk hilang.

- Campuran santan ini dapat meningkatkan sistem imunitas tubuh terhadap infeksi virus pada batuk pilek atau selesma, karena campuran santan ini mengandung berbagai zat yang dapat meningkatkan imunitas tubuh seperti asam laurat dan vitamin c, serta adanya kandungan zat besi dan antioksidan yang tinggi pada campuran tersebut.

\section{Referensi}

[1] Suryelita, S., Etika, S. B. and Kurnia, N. S. (2017) "ISOLASI DAN KARAKTERISASI SENYAWA STEROID DARI DAUN CEMARA NATAL (Cupressus funebris Endl.)”, EKSAKTA: Berkala Ilmiah Bidang MIPA, 18(01), pp. 8694. doi: 10.24036/eksakta/vol18-iss01/23.

[2] Prihatini, R. (2017) "PEMANFAATAN AIR KELAPA UNTUK MENINGKATKAN PERTUMBUHAN AKAR STEK TUNAS AKSILAR Andrographis paniculata Nees", EKSAKTA: Berkala Ilmiah Bidang MIPA, 18(02), pp. 62-68. doi: 10.24036/eksakta/vol18-iss02/54.

[3] Liza, Y. M., Yasin, R. C., Maidani, S. S., \& Zainul, R. (2018, October 9). SOL GEL : PRINCIPLE AND TECHNIQUE (A REVIEW). https://doi.org/10.31227/osf.io/2cuh8 
[4] Setiawan, I Made. 2009. Infection of Swine Influenza A H1N1 Triple-Reassortant (rH1N1) Virus in Human Vol. 59 No. 11

[5] Setiawan, I Made. 2008. Vaccine for Influenza Virus. Vol. 58 No. 12

[6] Susilaningrum, D. (2017) "PEMODELAN REGRESI LOGISTIK PADA FAKTOR YANG MEMPENGARUHI PHBS PADA RUMAH TANGGA PENDERITA TBC DI PESISIR SURABAYA", EKSAKTA: Berkala Ilmiah Bidang MIPA, 18(02), pp. 121128. doi: 10.24036/eksakta/vol18-iss02/65.

[7] Hapsari, Indri, Astuti, Ika Wahyu Budi. 2007. POLA PENGGUNAAN ANTIBIOTIKA PADA INFEKSI SALURAN PERNAPASAN AKUT PNEUMONIA BALITA PADA RAWAT JALAN PUSKESMAS I PURWAREJA. Vol 5, No 1

[8] Tompodung, Villy. 2014. BAKTERI AEROB PADA SPUTUM KELOMPOK GERIATRI DENGAN INFEKSI SALURAN PERNAPASAN DI PUSKESMAS RANOTANA WERU. Jurnal e-Biomedik (eBM). Vol 2, No 1

[9] Soedibyo, Soepardi, Yulianto, Arie, Wardhana, Wardhana. 2013. Profil Penggunaan Obat Batuk Pilek Bebas Pada Pasien Anak di Bawah Umur 6 Tahun.Vol 14, No 6

[10] Febriani, S. S., Yolanda, T., Arianti, V. A., \& Zainul, R. (2018, October 12). A Review Solid Stated : Principles and Methode. https://doi.org/10.31227/osf.io/7us4x

[11] Chatri, M., Mansyurdin, M., Bakhtiar, A. and Adnadi, P. (2017) "PERBANDINGAN KOMPONEN MINYAK ATSIRI ANTARA DAUN MUDA DAN DAUN DEWASA PADA HYPTIS SUAVEOLENS (L.)POIT", EKSAKTA: Berkala Ilmiah Bidang MIPA, 18(02), pp. 1-12. doi: 10.24036/eksakta/vol18-iss02/41.

[12] Sumarmin, R. (2018) "Pengaruh Ekstrak Kulit Buah Manggis (Garcinia mangostana L.) terhadap Histologis Pankreas Mencit (Mus musculus L. Swiss Webster) yang Diinduksi Sukrosa", EKSAKTA: Berkala Ilmiah Bidang MIPA, 19(1), pp. 100112. doi: 10.24036/eksakta/vol19-iss1/123.

[13] Subbaram, Kannan , Kannan, Hemalatha , Gatasheh, Mansour Khalil. 2017. Emerging Developments on Pathogenicity, Molecular Virulence, Epidemiology and Clinical Symptoms of Current Middle East Respiratory Syndrome Coronavirus (MERSCoV). Vol 24, No 2

[14] Setiawan, I Made. 2009. The Emergence of The New A Influenza Virus Subtype on Humans and The Possibility of Pandemic Event. Vol. 59 No. 3

[15] chaidir, z., Zainul, R., Nurakhbari, D., \& Salim, M. (2018, July 29). Optimization of Spirulina Platensis Culture for Antioxidant Production. https://doi.org/10.17605/OSF.IO/FD6E4 
[16] Dinata, A. A., Rosyadi, A. M., Hamid, S., \& Zainul, R. (2018, October 15). A Review CHEMICAL VAPOR DEPOSITION : PROCESS AND APPLICATION. https://doi.org/10.31227/osf.io/yfeau

[17] Shafitri, M., \& Zainul, R. (2019, February 3). Vanadium Pentaoksida (V2O5) : Termodinamika Molecular dan Interaksi Ion dalam Larutan. https://doi.org/10.31227/osf.io/jgmvd

[18] Gendrowahyuhono, Gendrowahyuhono , Wuryadi, Suharyono. 2004. A PRELIMINARY STUDY OF ENTEROVIRUS INFECTION AMONG CHILDREN IN PURWAKARTA, WEST JAVA, INDONESIA. Vol 9, No 2

[19] Angi, Andrijanto H., Wibawan, I Wayan Teguh, Murtini, Sri. 2009. Ability of Specific Antibody of Avian Influenza H5 to Several Viruses of H5N1 Field Isolates. Vol 32, No 1

[20] Sanjaya, H. (2017) "DEGRADASI METHYLENE BLUE MENGGUNAKAN KATALIS ZnO-PEG DENGAN METODE FOTOSONOLISIS", EKSAKTA: Berkala Ilmiah Bidang MIPA, 18(02), pp. 21-29. doi: 10.24036/eksakta/vol18-iss02/45.

[21] Iskandar, I., Horiza, H. and Fauzi, N. (2017) "EFEKTIVITAS BUBUK BIJI PEPAYA (Carica Papaya Linnaeaus) SEBAGAI LARVASIDA ALAMI TERHADAP KEMATIAN LARVA AEDES AEGYPTY TAHUN 2015", EKSAKTA: Berkala Ilmiah Bidang MIPA, 18(01), pp. 12-18. doi: 10.24036/eksakta/vol18-iss01/12.

[22] BARLINA, RINDENGAN. 2004. Potensi Buah Kelapa Muda Untuk Kesehatan dan Pengolahannya. Vol 3, No 2

[23] Alfionita, T., \& Zainul, R. (2019, January 29). Calcium Chloride (CaCl2) : Characteristics and Molecular Interaction in Solution. https://doi.org/10.31227/osf.io/m37xj

[24] Warlinda, Y. A., \& Zainul, R. (2019, January 29). Asam Posfat (H3PO4): Ionic Transformation of Phosphoric Acid in Aqueous Solution. https://doi.org/10.31227/osf.io/s3y8v

[25] Huda, N. (2017) "PENGARUH EKSTRAK SAMBILOTO (Andrographis paniculata Nees.) TERHADAP SIKLUS ESTRUS MENCIT (Mus musculus L. Swiss Webster)", EKSAKTA: Berkala Ilmiah Bidang MIPA, 18(02), pp. 69-76. doi: 10.24036/eksakta/vol18-iss02/55.

[26] Syafei, N. (2017) “ANALISA FENOMENA KOROSI PELAT PIPA BAJA KARBON API 5L-X65 DALAM LARUTAN 250 ML ASAM ASETAT DAN 4750 ML AQUADES PADA KONDISI GAS CO2 DAN H2S JENUH PADA SUHU RUANG", EKSAKTA: Berkala Ilmiah Bidang MIPA, 18(02), pp. 113-120. doi: 10.24036/eksakta/vol18-iss02/63. 
[27] Yuliani, F., \& Zainul, R. (2018, November 13). Analisis Termodinamika Molekul Magnesium Sulphate (MgSO4). https://doi.org/10.31227/osf.io/uxz4y

[28] Zainul, R. (2018, August 16). Effect of Temperature and Particle Motion against the ability of $\mathrm{ZnO}$ Semiconductor Photocatalyst in Humic Acid. https://doi.org/10.31227/osf.io/wnygb

[29] Rizki Saputra, M. and Sumarmin, R. (2018) "PENGARUH EKSTRAK DAUN SIRIH MERAH (Piper crocatum Ruiz \& Pav.) TERHADAP GLUKOSA DARAH MENCIT (Mus musculus L.) JANTAN YANG DIINDUKSI SUKROSA", EKSAKTA: Berkala Ilmiah Bidang MIPA, 19(1), pp. 43-55. doi: 10.24036/eksakta/vol19-iss 1/124.

[30] Sari, A. (2017) "POTENSI ANTIOKSIDAN ALAMI PADA EKSTRAK DAUN JAMBLANG (Syzigium cumini (L.) Skeels)", EKSAKTA: Berkala Ilmiah Bidang MIPA, 18(02), pp. 107-112. doi: 10.24036/eksakta/vol18-iss02/61.

[31] Zainul, R. (2018, August 16). Determination of the half-life and the quantum yield of $\mathrm{ZnO}$ semiconductor photocatalyst in humic acid. https://doi.org/10.31227/osf.io/e8a9x

[32] Mulia, M. (2017) "ISOLASI KUMARIN DARI KULIT BUAH LIMAU SUNDAI (Citrus nobilis Lour)", EKSAKTA: Berkala Ilmiah Bidang MIPA, 18(02), pp. 137-145. doi: 10.24036/eksakta/vol18-iss02/70.

[33] Sanjaya, H. (2018) "DEGRADASI METIL VIOLET MENGGUNAKAN KATALIS ZnO-TiO2 SECARA FOTOSONOLISIS", EKSAKTA: Berkala Ilmiah Bidang MIPA, 19(1), pp. 91-99. doi: 10.24036/eksakta/vol19-iss1/131.

[34] Parbuntari, H., Prestica, Y., Gunawan, R., Nurman, M. and Adella, F. (2018) "Preliminary Phytochemical Screening (Qualitative Analysis) of Cacao Leaves (Theobroma cacao L.)", EKSAKTA: Berkala Ilmiah Bidang MIPA, 19(2), pp. 40-45. doi: 10.24036/eksakta/vol19-iss2/142.

[35] Tutuarima, T. (2017) "SIFAT FISIK DAN KIMIA MARMALADE JERUK KALAMANSI (Citrus microcarpa) : KAJIAN KONSENTRASI PEKTIN DAN SUKROSA Physical and Chemical Properties of Marmalade Citrus of Calamondin (Citrus microcarpa): Study of Pectin and Sucrose Concentrations", EKSAKTA: Berkala Ilmiah Bidang MIPA, 18(02), pp. 164-172. doi: 10.24036/eksakta/vol18-iss02/73. 